A N N A L E S

UNIVERSITATIS MARIAE CURIE-SKŁODOWSKA LUBLIN - POLONIA

VOL. XXIX, 1

SECTIO J

2016

Uniwersytet Marii Curie-Skłodowskiej w Lublinie. Wydział Pedagogiki i Psychologii

\title{
PAULINA MANACHIEWICZ
}

paulina.manachiewicz@wp.pl

Sens życia osób starszych - analiza empiryczna

The Sense of Life of the Eldery - Empirical Analysis

\section{STRESZCZENIE}

Starzenie się nie jest zjawiskiem nowym. Ludzie od zawsze się starzeją i to jest normalne. Na przestrzeni ostatnich lat można jednak zauważyć, że społeczeństwo w Polsce się starzeje. Dzieje się tak, ponieważ postęp w medycynie daje możliwość wydłużenia życia ludzkiego, przy czym liczba urodzeń drastycznie spada. Osoby starsze stają się coraz liczniejszą grupą, dlatego ważne jest poznanie specyfiki procesu starzenia się oraz potrzeb, jakie mają ludzie starsi. Istotne jest również, by skupić się na problemach natury egzystencjalnej, m.in. na poczuciu sensu życia osób w podeszłym wieku.

Słowa kluczowe: starość; starzenie; osoby starsze; sens życia

\section{WPROWADZENIE}

Pytania o sens życia z pewnością dotyczą każdego z nas. Odnalezienie go jest niezmiernie ważne, ponieważ w dzisiejszych czasach, gdzie wartość materialna zyskuje coraz większe znaczenie, człowiek może czuć się zagubiony, przez co nie wie, w jakim kierunku w swym życiu powinien zmierzać. Wiele osób zapomina o tym, że życie ludzkie jest wartością samą w sobie. Ludzie wolą rozmawiać o tym, co udało im się w życiu zdobyć. Gdy człowiek przelicza swą wartość na posiadane przez siebie rzeczy, w momencie ich straty może również utracić sens swojego życia, co z kolei może doprowadzić do złej kondycji zdrowia fizycznego i psychicznego. Powyższą tezę potwierdzają amerykańscy naukowcy z Mt. Sinai 
St. Luke's Roosevelt Hospital. Zbadali oni związek poczucia sensu życia z ryzykiem śmierci z dowolnego powodu. Zdaniem naukowców „przekonanie o wysokiej wartości i celowości własnego życia obniża (...) ryzyko śmierci z dowolnego powodu o 23\%" (Zegarow 2015).

Czym jest poczucie sensu życia? Zdaniem T. Sikorskiego (1989, s. 238) jest to ,idea wyrażająca przeświadczenie, że istnieje odpowiedź pozytywna na podstawowe pytania człowieka: czy życie ma jakiś rozumny cel, czy warto żyć i po co - mimo cierpienia i śmierci, mimo nieszczęść, niesprawiedliwości i nienawiści”.

Sytuacja osób starszych w Polsce z całą pewnością jest zagadnieniem, które należy wnikliwie badać i analizować. Dlaczego? Ponieważ społeczeństwo staje się coraz starsze. Powyższe stwierdzenia poświadcza Główny Urząd Statystyczny. Według prognoz GUS, zawartych w dokumencie pt. Sytuacja demograficzna osób starszych $i$ konsekwencje starzenia się struktury ludności w świetle prognozy na lata 2014-2050, przygotowanym dla sejmowej komisji polityki senioralnej,

(...) w latach 2014-2020 i po 2035 r. spodziewany jest znaczny przyrost ludności w starszym wieku w miastach województw: dolnośląskiego, lubuskiego, łódzkiego, mazowieckiego, pomorskiego i wielkopolskiego, podczas gdy w części miejskiej pozostałych województw tendencja wzrostowa utrzyma się przez cały okres objęty prognozą. W wyniku przewidywanych zmian, w ciągu 37 lat objętych prognozą, w większości województw wzrost udziału ludności w starszym wieku będzie oscylował w granicach od 19 do 23,7 p. proc. (GUS 2014, s. 36).

Biorąc pod uwagę to, że liczba osób w wieku podeszłym stale rośnie, konieczne są rozważania na temat potrzeb i problemów tej grupy społecznej.

\section{STAROŚĆ, STARZENIE SIE I POCZUCIE SENSU ŻYCIA - UJĘCIA DEFINICYJNE}

Aby mówić o zagadnieniach związanych ze starością, starzeniem się i poczuciem sensu życia, należy najpierw wyjaśnić te pojęcia. Starość i starzenie się nie są możliwe do jednoznacznego zdefiniowania. Formułowanie ich definicji jest zależne od wielu czynników, m.in. wieku i indywidualnych preferencji. Zdaniem Z. Szaroty (2004, s. 43) i E. Trafiałek (2006, s. 27) starość rozpoczyna się w momencie, gdy koniecznością staje się zmiana ról społecznych, jakie były dotychczas pełnione przez osoby w wieku podeszłym. „Jeżeli mowa o starości, to na ogół kojarzy się ją ze wszystkimi negatywnymi cechami ostatniego okresu życia, a więc z różnego rodzaju przejawami upadku sił fizycznych i psychicznych, z koniecznością trwałej opieki w zakresie zdrowia i warunków życia" (Dyczewski 1994, s. 36). Zdaniem E. Trafiałek starość jest

(...) naturalną fazą życia, następującą po młodości i dojrzałości, wieńczącą dynamiczny proces starzenia się. Określana mianem „końcowej tercji życia”, utożsamiana jest ze spadkiem wydolności organizmu, utratą mobilności, osłabieniem sił immunologicznych (starość biologiczna, fizjologicz- 
na), ograniczeniem zdolności przystosowania się do wszelkich zmian, a w kontekście socjoekonomicznym - nierzadko też z pauperyzacją, samotnością (starość psychiczna), koniecznością korzystania z pomocy innych (starość ekonomiczna) i funkcjonowaniem na marginesie życia społecznego (starość społeczna) (Trafiałek 2006, s. 69).

Starość definiuje się również jako „końcowy etap w życiu człowieka rozpoczynający się wraz z osiągnięciem określanego konwencjonalnie »progu starości«. Jest dynamicznym i synergicznym związkiem procesów biologicznych i psychicznych oraz zmian w sferze społecznej aktywności jednostki" (Szatur-Jaworska 2000, s. 33-34). Definicja ta zwraca uwagę na to, że starość jest zależna od doświadczenia danej osoby, a jej początek jest indywidualnym procesem. „Biologowie i lekarze określają starość jako okres życia ustroju po wieku dojrzałym, charakteryzujący się obniżeniem funkcji życiowych i szeregiem zmian w poszczególnych układach i narządach. W ujęciu tym podkreśla się zarazem konieczność odróżnienia postępującego procesu starzenia się od fazy starości długotrwałej" (Szarota 2004, s. 22-23).

E. Trafiałek wyróżnia następujące progi wyznaczające początek starości: próg kalendarzowy, którym jest osiągnięcie wieku emerytalnego; próg biologiczny, którego wyznacznikiem jest funkcjonalna sprawność organizmu; próg prawny, utożsamiany z ustawowym przymusem rezygnacji z aktywności zawodowej; próg ekonomiczny, który ma związek ze spadkiem dochodów; próg społeczny, związany z utratą prestiżu i ról społecznych; próg technologiczny, wyznaczony występowaniem lęku przed nowoczesnymi urządzeniami (Trafiałek 2003, s. 580).

Zdaniem A. Grzywny starzenie się to

(...) zmniejszenie zdolności reagowania na stresy, które postępuje z upływem czasu, co powoduje naturalne i nieodwracalne uszkodzenia wewnątrzkomórkowe, których organizm nie potrafi już naprawić. Powoduje to utratę równowagi wewnętrznej organizmu, co zwiększa ryzyko wystąpienia chorób. Dla starzenia się znaczenie mają pewne zasoby genetyczne, ale wpływają na ten proces także szkodliwe czynniki środowiskowe, np. starzenie się skóry w wyniku działania słonecznego promieniowania ultrafioletowego czy starzenie się płuc pod wpływem toksyn zawartych w zanieczyszczonym powietrzu lub dymie tytoniowym (Grzywna 2013, s. 16).

Wiele koncepcji biologiczno-medycznych głosi, że moment rozpoczęcia starzenia się organizmu jest niemożliwy do określenia, ponieważ już w pierwszych miesiącach życia miliony komórek obumierają, a w ich miejscu powstaje duża ilość nowych komórek. W potocznej opinii proces starzenia rozpoczyna się w momencie zachwiania równowagi metabolicznej organizmu. Jest to naturalny i uniwersalny proces, który zachodzi w życiu człowieka od momentu poczęcia aż do śmierci (Szarota 2004, s. 23).

W miarę starzenia się w organizmie człowieka występują stopniowo schorzenia, zmniejszają się również wszystkie ważne tkanki - mózgu, płuc, serca, wątroby, mięśni i kości. W momencie osiągnięcia wieku średniego człowiek powinien 
pogodzić się z faktem, iż znacznemu pogorszeniu ulegają warunki jego funkcjonowania biologicznego i społecznego. Po osiągnięciu 60. roku życia odczuwa się dotkliwie opóźnienie procesów myślowych i zaburzenia pamięci. Osoby w starszym wieku zauważają, że czytanie sprawia im większą trudność. Słuch także pogarsza się z wiekiem. Płuca i klatka piersiowa stają się mniej elastyczne, co pogarsza możliwości oddechowe. Osoby starsze z tego powodu są bardziej podatne na choroby i infekcje (Pichalski 2014, s. 11).

Pytania o sens ludzkiej egzystencji dotyczą każdego człowieka, bez względu na to, w jakim jest wieku. Dla osób starszych charakterystyczne są doświadczenia wewnętrzne lub procesy myślowe, które polegają na spoglądaniu za siebie i ocenianiu swego życia (Izdebski, Polak 2005, s. 188).

Pojęcie sensu życia jest niezmiernie trudne do zdefiniowania. Dlaczego tak się dzieje? Odpowiedź na to pytanie można znaleźć u J. Mizińskiej. Zdaniem autorki zdefiniowanie sensu jest trudne, ponieważ należy ono do pojęć pierwszych, elementarnych, a co za tym idzie - niedefiniowalnych. Sens jest bardziej domeną intuicji niż rozumu i odnosi się głównie do podmiotu - podmiotu myślącego, świadomego i samoświadomego (Mizińska 2011, s. 31). Sens życia jest związany z ogólnym zadowoleniem, które dotyczy takich aspektów egzystencji, jak: zdrowie, poczucie, że jesteśmy w stanie zrealizować swe zamierzenia, możemy ufać innym, sprawujemy kontrolę nad wydarzeniami itp. Zadowolenie dotyczy różnych sfer życia: sfery osobistej, rodzinnej, kulturalnej, zawodowej i wielu innych. Zadowolenie z życia i poczucie, że jest się szczęśliwym, jest związane z poczuciem sensu życia, lecz nie jest z nim tożsame. Stąd też mogą być osoby ogólnie zadowolone z życia, ale nieodkrywające w nim sensu i odwrotnie. Istnieją jeszcze dwie inne kategorie ludzi. Są to osoby niezadowolone, które nie dostrzegają w swym życiu sensu, a także ludzie, którzy oceniają swoje życie jako sensowne i dające poczucie zadowolenia. Pytania o sens życia zazwyczaj pojawiają się w momentach ważnych i przełomowych dla człowieka (Mariański 2013, s. 27-28).

Potrzeba sensu życia jest związana z innymi potrzebami natury psychicznej. Brak sensu i nieumiejętność określenia planów przyszłościowych są ściśle związane z kryzysem wartości, a poza tym prowadzą do frustracji egzystencjalnej. W tym przypadku wszelka działalność, jaką podejmuje człowiek w kryzysie, traci na wartości, ponieważ nie wytycza on sobie żadnych celów. To w rezultacie wywołuje uczucie moralnej samotności. Przykładem samotności moralnej połączonej z samotnością fizyczną i psychiczną jest stan nazwany osamotnieniem (Pichalski 2014, s. 109).

Wejście w okres starości nie oznacza, że człowiek jest skazany na samotność. Ważna jest postawa, jaką przejawia on w stosunku do własnej starości. Warunkuje się ona przez całe życie człowieka. Według L. Dyczewskiego 
(...) narodzinom i młodości towarzyszy pewność wejścia w nowy świat. Jeżeli taka nadzieja towarzyszy starości, jeżeli człowiek stary ma pewność, że ze śmiercią wszystko się nie kończy, że nie kończy się on jako człowiek, lecz żyje nadal, wówczas i starość, i śmierć nabierają specjalnego znaczenia i głębokiego sensu, prowadzą go bowiem ku nowemu życiu, a nie ku zagładzie. Owa wizja dalszego życia w nowym świecie nadaje sens cierpieniu, niedołęstwu i wysiłkom okresu starości. Sama zaś starość widziana jest wówczas jako jeden z etapów w osiąganiu pełnego człowieczeństwa - i to o tyle ważnego, że w nim dokonuje człowiek podsumowania i oceny wszystkiego, co przeżył, przemyślał i zdziałał (Dyczewski 1994, s. 89-90).

\section{METODOLOGIA BADAŃ WŁASNYCH}

W niniejszym artykule przedmiotem badań jest poczucie sensu życia osób starszych. Cel pracy ma charakter poznawczy, zmierza do diagnozy czynników mających wpływ na poczucie sensu życia osób starszych oraz do poznania stopnia, w jakim deklarowany sens życia został przez nich osiągnięty.

Główny problem badawczy przyjął postać następującego pytania: jaki związek istnieje pomiędzy uwzględnionymi $\mathrm{w}$ badaniach czynnikami osobowymi i społecznymi a poczuciem sensu życia u osób starszych? Aby odpowiedzieć na to pytanie, konieczne jest określenie czynników osobowych i społecznych, które warunkują poczucie sensu życia seniorów. W niniejszym badaniu zmienne niezależne to: płeć, autodeklaracja religijna, wiek, sytuacja materialna, miejsce zamieszkania, stan zdrowia fizycznego, wykształcenie, posiadanie potomstwa. Zmienną zależną była natomiast skala poczucia sensu życia. W artykule została przedstawiona korelacja z wybranymi zmiennymi niezależnymi.

Ze względu na zakres prowadzonych badań zastosowano metodę sondażu diagnostycznego, którą T. Pilch definiuje jako

(...) sposób gromadzenia wiedzy o atrybutach strukturalnych i funkcjonalnych oraz dynamice zjawisk społecznych, opiniach i poglądach wybranych zbiorowości, nasilaniu się i kierunkach rozwoju określonych zjawisk i wszelkich innych zjawiskach instytucjonalnie niezlokalizowanych - posiadających znaczenie wychowawcze - w oparciu o specjalnie dobraną grupę reprezentującą populację generalną, w której badane zjawisko występuje (Pilch 1995, s. 51).

Metodą, którą posłużono się podczas przeprowadzania badań, była ankieta, a narzędziem badawczym był kwestionariusz ankiety składający się z dwóch części. Pierwsza część kwestionariusza to pytania o czynniki osobowe i społeczne osób badanych, a także krótka instrukcja postępowania oraz informacja o celu przeprowadzonego badania. Pozostałe części kwestionariusza tworzy skala PIL (Purpose in Life Test), która jest przeznaczona do badania poczucia sensu życia. Narzędzie to jest standaryzowane. Test PIL został opracowany przez J.C. Crumbaugha i L.T. Maholicka, a przekładu na język polski dokonała Z. Płużek (Juza 2012, s. 186). Test składa się z następujących podskal: afirmacja życia, akceptacja siebie, świadomość celu, poczucie wolności, ocena przyszłości, postawa 
wobec śmierci. Narzędzie zostało podzielone na trzy części. Część pierwsza to lista 20 twierdzeń rozpiętych na siedmiostopniowej skali. Respondent miał za zadanie określić, w jakim stopniu dane twierdzenie jest zgodne $\mathrm{z}$ jego przekonaniami, przy tym był proszony o unikanie cyfry „4”. Druga część testu składała się z 14 niedokończonych zdań. Zadaniem respondenta było dokończenie każdego ze zdań pierwszą myślą, jaka przyszła mu do głowy po jego przeczytaniu. W części trzeciej badany miał za zadanie napisać kilka zdań na temat swych dążeń, celów i ambicji życiowych.

\section{CHARAKTERYSTYKA GRUPY BADAWCZEJ}

Materiał badawczy został zgromadzony w 2015 r. W badaniach wzięło udział 62 seniorów mieszkających samodzielnie lub przy rodzinie. Badania zostały przeprowadzone zarówno na obszarach miejskich, jak i wiejskich. Udział w badaniu był dobrowolny.

W niniejszych badaniach liczniejszą grupę stanowiły kobiety $(69,35 \%)$. Prawie co trzecia osoba ankietowana była płci męskiej (30,65\%). Zróżnicowanie pod względem wieku respondentów jest również dość widoczne. Najliczniejszą grupę stanowiły osoby między 70. a 74. rokiem życia (40,32\%). Średnio co trzecia osoba badana była w wieku 60-69 lat (30,64\%). Podobny wynik osiągnęły osoby w wieku $75-84$ lat $(27,41 \%)$. Najmniejszą grupę stanowiły osoby w wieku sędziwym (1,61\%). Najbardziej liczną grupę pod względem miejsca zamieszkania stanowiły osoby mieszkające w małych miastach, w których liczba mieszkańców nie przekracza 100 tys. $(45,16 \%)$. Co trzeci respondent mieszkał poza miastem (33,87\%), natomiast co piąta osoba ankietowana zamieszkiwała na terenie dużego miasta $(20,97 \%)$. Okazało się, że miejsce zamieszkania w sposób istotny różnicuje poczucie sensu życia seniorów.

Innym czynnikiem warunkującym poczucie sensu życia osób starszych jest autodeklaracja religijna. Respondentów, którzy deklarują, iż są osobami wierzącymi, pod względem liczebności było najwięcej, bo aż 42 (67,74\%). Prawie co trzecia osoba biorąca udział w badaniach uważa się za osobę głęboko wierzącą $(29,03 \%)$. Ankietowanych mających problem ze swą autodeklaracją religijną było niewielu (zaledwie 3,22\%), natomiast osób niewierzących w badaniu nie odnotowano.

Ostatnim czynnikiem, mającym istotny statystycznie wpływ na poczucie sensu życia, okazał się stan zdrowia osób badanych. Biorąc pod uwagę stan zdrowia, respondenci podzielili się na trzy wiodące grupy. Pierwsza oceniła swój stan zdrowia jako dobry $(33,87 \%)$. Prawie co trzecia osoba badana miała problem z określeniem swego stanu zdrowia, również prawie co trzeci respondent ocenił swój stan zdrowia jako zły $(30,64 \%)$. Skrajne odpowiedzi natomiast wybrała najmniej- 
sza liczba ankietowanych. Jako bardzo dobry stan swego zdrowia określiła tylko jedna osoba $(1,61 \%)$, natomiast trzy osoby $(4,83 \%)$ uważały, że ich stan zdrowia jest bardzo zły.

\section{OSOBOWE I SPOŁECZNE UWARUNKOWANIA POCZUCIA SENSU ŻYCIA OSÓB STARSZYCH - ANALIZA BADAŃ WŁASNYCH}

Podczas analizy przebadano związek między czynnikami demograficznymi a poczuciem sensu życia osób starszych. Wyniki przedstawiają tab. 1-5. Czynniki demograficzne uwzględnione w badaniach to: płeć, wiek, miejsce zamieszkania, autodeklaracja dotycząca zdrowia i religii,

Tab. 1. Płeć respondentów

\begin{tabular}{|l|c|c|c|c|c|c|c|c|}
\hline \multirow{2}{*}{\multicolumn{1}{|c|}{ Podskale testu PIL }} & \multicolumn{3}{|c|}{ Kobiety } & \multicolumn{3}{c|}{ Mężczyźni } & \multicolumn{2}{c|}{$\begin{array}{c}\text { Test U Man- } \\
\text { na-Whitneya }\end{array}$} \\
\cline { 2 - 10 } & $\mathrm{M}$ & $\mathrm{SD}$ & $\mathrm{N}$ & $\mathrm{M}$ & $\mathrm{SD}$ & $\mathrm{N}$ & $\mathrm{Z}$ & $\mathrm{p}$ \\
\hline Afirmacja życia & 4,87 & 0,818 & 43 & 4,50 & 0,907 & 19 & 1,178 & 0,083 \\
\hline Akceptacja siebie & 5,10 & 0,922 & 43 & 4,78 & 0,951 & 19 & 1,122 & 0,693 \\
\hline Świadomość celu & 4,67 & 1,035 & 43 & 4,47 & 0,951 & 19 & 0,629 & 0,058 \\
\hline Poczucie wolności & 4,45 & 1,224 & 43 & 3,76 & 1,347 & 19 & 1,894 & 0,528 \\
\hline Ocena przyszłości & 4,72 & 1,076 & 43 & 4,47 & 1,006 & 19 & 0,394 & 0,261 \\
\hline Postawa wobec śmierci & 4,63 & 1,355 & 43 & 5,13 & 0,831 & 19 & $-1,730$ & 0,238 \\
\hline
\end{tabular}

Źródło: opracowanie własne.

Analizując wyniki badań pod względem struktury płci, można wysnuć wniosek, że kobiety posiadają wyższy poziom poczucia sensu życia niż mężczyźni. Kobiety najczęściej w sposób pozytywny odnosiły się do pytań dotyczących akceptacji siebie, natomiast mężczyźni wykazali pozytywną postawę wobec własnej śmierci. Zarówno w przypadku kobiet, jak i mężczyzn najniższe wartości uzyskały odpowiedzi na pytania dotyczące poczucia ich wolności, jednakże w obu przypadkach wynik nie klasyfikował się poniżej średniej, która dla całej skali wynosi 3,5. Analiza statystyczna nie wykazała, by płeć respondentów w sposób istotny wpływała na ich poczucie sensu życia.

Biorąc pod uwagę wiek respondentów, możemy zauważyć, że wyższy poziom poczucia sensu życia posiadają osoby w wieku powyżej 70 lat. Osoby poniżej 70. roku życia również charakteryzują się wysokim wskaźnikiem poczucia sensu życia, lecz podczas przeprowadzanych badań ich wyniki uplasowały się po- 
Tab. 2. Wiek respondentów

\begin{tabular}{|l|c|c|c|c|c|c|c|c|c|c|c|}
\hline \multirow{2}{*}{ Podskale testu PIL } & \multicolumn{3}{|c|}{$60-69$ lat } & \multicolumn{3}{c|}{$70-74$ lat } & \multicolumn{3}{c|}{75 i więcej } & \multicolumn{3}{c|}{$\begin{array}{c}\text { Analiza } \\
\text { wariancji }\end{array}$} \\
\cline { 2 - 13 } & M & SD & N & M & SD & N & M & SD & N & F & p \\
\hline Afirmacja życia & 4,55 & 0,988 & 19 & 4,89 & 0,806 & 25 & 4,79 & 0,777 & 18 & 0,883 & 0,418 \\
\hline Akceptacja siebie & 4,75 & 0,955 & 19 & 5,20 & 0,850 & 25 & 5,01 & 1,013 & 18 & 1,236 & 0,297 \\
\hline Świadomość celu & 4,57 & 1,300 & 19 & 4,66 & 0,714 & 25 & 4,57 & 1,059 & 18 & 0,058 & 0,943 \\
\hline Poczucie wolności & 4,07 & 1,652 & 19 & 4,32 & 1,274 & 25 & 4,30 & 0,877 & 18 & 0,213 & 0,808 \\
\hline Ocena przyszłości & 4,42 & 1,272 & 19 & 4,76 & 0,959 & 25 & 4,72 & 0,943 & 18 & 0,619 & 0,542 \\
\hline $\begin{array}{l}\text { Postawa wobec } \\
\text { śmierci }\end{array}$ & 4,60 & 1,048 & 19 & 4,86 & 1,016 & 25 & 4,88 & 1,195 & 18 & 0,406 & 0,668 \\
\hline
\end{tabular}

Źródło: opracowanie własne.

niżej wyników osiągniętych przez osoby od nich starsze. Podobnie jak w przypadku płci, osoby starsze najwyższy wynik osiągnęły w pytaniach dotyczących akceptacji siebie, a najniższy w pytaniach dotyczących poczucia ich wolności. Warto zwrócić uwagę na aspekt dotyczący postawy seniorów wobec śmierci. W przypadku osób, które mają więcej niż 70 lat, postawa wobec śmierci jest bardziej pozytywna niż u osób przed 70. rokiem życia. W przypadku grupy wiekowej 70-74 lata oraz grupy wiekowej 75 lat i więcej to właśnie odpowiedzi dotyczące postawy wobec własnej śmierci uzyskały jeden z najwyższych wyników. Na podstawie powyższych danych możliwe jest wysnucie wniosku, że najstarsi respondenci mają większą świadomość nadchodzącego końca swego życia i akceptują ten fakt. Analiza statystyczna jednak nie wykazała, by wiek osób badanych w sposób statystycznie istotny wpływał na udzielane odpowiedzi.

Jak wcześniej wspomniano, miejsce zamieszkania w sposób istotny statystycznie wpłynęło na poczucie sensu życia osób badanych.

Biorąc pod uwagę czynnik, jakim jest miejsce zamieszkania, najwyższy poziom sensu życia wykazały osoby zamieszkujące tereny wiejskie. Osoby mieszkające poza miastem najwyższe wyniki uzyskały przy pytaniach dotyczących akceptacji oraz świadomości celu. Może to wynikać z faktu, iż seniorzy zamieszkujący tereny wiejskie mogli być wychowani w sposób inny niż osoby pochodzące z miast, poza tym mogą oni również posiadać inne priorytety w życiu. To z kolei może przekładać się na wyższą świadomość celu swej egzystencji. Analiza statystyczna wykazała, że miejsce zamieszkania w sposób istotny wpływa na poczucie świadomości celu $(\mathrm{p}=0,007)$. Osoby zamieszkujące mniejsze miasta mają większą świadomość celu swego życia niż osoby z dużych miast $(\mathrm{p}=0,006)$. 
Tab. 3. Miejsce zamieszkania seniorów

\begin{tabular}{|c|c|c|c|c|c|c|c|c|c|c|c|c|}
\hline \multirow{2}{*}{$\begin{array}{l}\text { Podskale } \\
\text { testu PIL }\end{array}$} & \multicolumn{3}{|c|}{$\begin{array}{l}\text { I. Duże } \\
\text { miasto }\end{array}$} & \multicolumn{3}{|c|}{ II. Wieś } & \multicolumn{3}{|c|}{$\begin{array}{l}\text { III. Małe } \\
\text { miasto }\end{array}$} & \multicolumn{2}{|c|}{$\begin{array}{c}\text { Test Kruska- } \\
\text { la-Wallisa }\end{array}$} & \multirow{2}{*}{$\begin{array}{l}\text { Różnice } \\
\text { istotne sta- } \\
\text { tystycznie }\end{array}$} \\
\hline & M & SD & $\mathrm{N}$ & M & SD & $\mathrm{N}$ & M & SD & $\mathrm{N}$ & $\mathrm{H}$ & $\mathrm{p}$ & \\
\hline $\begin{array}{l}\text { Afirmacja } \\
\text { życia }\end{array}$ & 4,43 & 1,122 & 13 & 5,04 & 0,758 & 21 & 4,70 & 0,745 & 28 & 3,266 & 0,195 & Brak \\
\hline $\begin{array}{l}\text { Akceptacja } \\
\text { siebie }\end{array}$ & 4,71 & 1,087 & 13 & 5,11 & 0,939 & 21 & 5,07 & 0,862 & 28 & 1,126 & 0,569 & Brak \\
\hline $\begin{array}{l}\text { Świadomość } \\
\text { celu }\end{array}$ & 3,94 & 1,070 & 13 & 5,11 & 0,974 & 21 & 4,54 & 0,817 & 28 & 9,930 & 0,007 & $\begin{array}{c}\mathrm{I}-\mathrm{II} \\
\mathrm{p}=0,006\end{array}$ \\
\hline $\begin{array}{l}\text { Poczucie } \\
\text { wolności }\end{array}$ & 4,34 & 1,360 & 13 & 4,52 & 1,520 & 21 & 3,98 & 1,049 & 28 & 3,204 & 0,201 & Brak \\
\hline $\begin{array}{l}\text { Ocena } \\
\text { przyszłości }\end{array}$ & 4,26 & 1,092 & 13 & 5,00 & 1,118 & 21 & 4,55 & 0,936 & 28 & 4,240 & 0,120 & Brak \\
\hline $\begin{array}{l}\text { Postawa } \\
\text { wobec śmierci }\end{array}$ & 4,30 & 1,090 & 13 & 5,02 & 1,134 & 21 & 4,83 & 0,972 & 28 & 2,936 & 0,230 & Brak \\
\hline
\end{tabular}

Źródło: opracowanie własne.

Religia osobie starzejącej się, która doskonale zdaje sobie sprawę ze swych słabości i kruchości egzystencji, oferuje nowe moce i ukazuje jej, że własnego życia nie może brać tylko takim, jakim je aktualnie widzi, lecz powinna je umieszczać w perspektywie wieczności. Osoby religijne akceptują śmierć mimo jej tragiczności i tajemniczości, patrzą na nią pozytywnie, przyznają jej określoną wartość i sens, ponieważ religia wiedzie do wszechmocy zrozumienia ostatecznego sensu życia i wiecznego istnienia. Religia rozbudza w człowieku w podeszłym wieku życiowy optymizm, budzi w nim nadzieję bytu wiecznego, zobaczenia się z wszystkimi bliskimi osobami, które w czasie ziemskiego życia kochał, dopełnia sprawiedliwości i spełnienia w miłości - dwóch ideałów, które przez całe życie człowiek pragnie realizować (Dyczewski 1994, s. 105-107).

Jak wynika z badań, religia ma również wpływ istotny statystycznie na poczucie sensu życia osób starszych, a dokładnie na ich subiektywną ocenę przyszłości $(\mathrm{p}=0,004)$ oraz przejawianą przez nich postawę wobec śmierci $(\mathrm{p}=0,025)$.

Analiza statystyczna wykazała, że respondenci, którzy deklarują, że są osobami głęboko wierzącymi, częściej udzielali pozytywnych odpowiedzi na pytania dotyczące oceny przyszłości i postawy wobec śmierci. Taki stan rzeczy może wynikać z faktu, iż osoby głęboko wierzące w sposób bardziej optymistyczny spoglądają w przyszłość i z większym spokojem czekają na to, co los im przyniesie. Odpowiedzi wszystkich respondentów miały charakter pozytywny. W badaniu nie wzięły udziału osoby, które nie identyfikowały się z żadną religią. Dwo- 
Tab. 4. Autodeklaracja religijna osób starszych

\begin{tabular}{|l|c|c|c|c|c|c|c|c|}
\hline \multirow{2}{*}{\multicolumn{1}{|c}{ Podskale testu PIL }} & \multicolumn{2}{|c|}{ Głęboko wierząca } & \multicolumn{3}{c|}{ Wierząca } & \multicolumn{2}{c|}{$\begin{array}{c}\text { Test U Manna- } \\
\text { Whitneya }\end{array}$} \\
\cline { 2 - 10 } & $\mathrm{M}$ & $\mathrm{SD}$ & $\mathrm{N}$ & $\mathrm{M}$ & $\mathrm{SD}$ & $\mathrm{N}$ & $\mathrm{Z}$ & $\mathrm{p}$ \\
\hline Afirmacja życia & 5,12 & 0,741 & 18 & 4,70 & 0,761 & 42 & 1,834 & 0,066 \\
\hline Akceptacja siebie & 5,37 & 0,847 & 18 & 4,93 & 0,896 & 42 & 1,486 & 0,137 \\
\hline Świadomość celu & 4,87 & 0,864 & 18 & 4,59 & 0,992 & 42 & 1,031 & 0,302 \\
\hline Poczucie wolności & 4,50 & 0,874 & 18 & 4,26 & 1,331 & 42 & 0,741 & 0,458 \\
\hline Ocena przyszłości & 5,25 & 0,862 & 18 & 4,48 & 0,966 & 42 & 2,809 & 0,004 \\
\hline Postawa wobec śmierci & 5,30 & 1,100 & 18 & 4,60 & 1,009 & 42 & 2,237 & 0,025 \\
\hline
\end{tabular}

Źródło: opracowanie własne.

je respondentów miało problem ze swą autodeklaracją religijną, lecz ze względu na ich małą ilość analiza statystyczna udzielonych przez nich odpowiedzi nie mogła zostać wykonana.

Dokonując korelacji poczucia sensu życia seniorów z ich deklarowanym stanem zdrowia fizycznego, wykazano zależności, które pod względem statystycznym są istotne. Zależności te zostały ujawnione w podskalach PIL dotyczących afirmacji życia oraz akceptacji siebie $(\mathrm{p}=0,007)$.

Biorąc pod uwagę wyniki zamieszczone w tab. 5, należy stwierdzić, że osoby, oceniające swój stan zdrowia jako dobry lub bardzo dobry, w przypadku wyżej wymienionych skal, mają bardziej pozytywny stosunek do życia $(\mathrm{p}=0,001)$ oraz akceptują siebie $(\mathrm{p}=0,000)$ - w przeciwieństwie do osób, które swój stan zdrowia oceniają jako zły lub bardzo zły. $Z$ analizy wynika również, że osoby mające problem z określeniem swego stanu zdrowia (udzielające odpowiedzi „trudno powiedzieć") w sposób bardziej pozytywny odpowiadały na pytania dotyczące akceptacji siebie niż osoby, które negatywnie odnosiły się do swego stanu zdrowia. W tym przypadku poziom istotności statystycznej wynosi 0,008 . Seniorzy mający problemy zdrowotne najbardziej pozytywnie odnosili się do pytań dotyczących ich postawy wobec śmierci. Pozostałe dwie grupy najwyższe wyniki uzyskały przy pytaniach z kategorii „afirmacja życia”.

\section{ZAKOŃCZENIE}

Zaprezentowane wyniki badań wskazują, że osoby starsze charakteryzują się wysokim natężeniem poczucia sensu życia. Seniorzy są zadowoleni ze swego życia i pomimo starości posiadają wyraźnie określone cele i dążenia. Zdecydowana 
Tab. 5. Autodeklaracja dotycząca stanu zdrowia osób badanych

\begin{tabular}{|c|c|c|c|c|c|c|c|c|c|c|c|c|}
\hline \multirow{2}{*}{$\begin{array}{l}\text { Podskale } \\
\text { testu PIL }\end{array}$} & \multicolumn{3}{|c|}{$\begin{array}{c}\text { I. Bardzo dobry/ } \\
\text { dobry }\end{array}$} & \multicolumn{3}{|c|}{$\begin{array}{l}\text { II. Trudno } \\
\text { powiedzieć }\end{array}$} & \multicolumn{3}{|c|}{$\begin{array}{l}\text { III. Zły/ } \\
\text { bardzo zły }\end{array}$} & \multicolumn{2}{|c|}{$\begin{array}{c}\text { Analiza } \\
\text { wariancji }\end{array}$} & \multirow{2}{*}{\begin{tabular}{|c} 
Różnice \\
istotne sta- \\
tystycz- \\
nie (Test \\
NIR)
\end{tabular}} \\
\hline & M & SD & $\mathrm{N}$ & M & $\mathrm{SD}$ & $\mathrm{N}$ & M & SD & $\mathrm{N}$ & $\mathrm{F}$ & $\mathrm{p}$ & \\
\hline $\begin{array}{l}\text { Afirmacja } \\
\text { życia }\end{array}$ & 5,14 & 0,708 & 22 & 4,77 & 0,728 & 18 & 4,36 & 0,936 & 22 & 5,263 & 0,007 & $\begin{array}{c}\mathrm{I}-\mathrm{III} \\
\mathrm{p}=0,001\end{array}$ \\
\hline $\begin{array}{l}\text { Akcepta- } \\
\text { cja siebie }\end{array}$ & 5,45 & 0,79384 & 22 & 5,16 & 0,923 & 18 & 4,43 & 0,806 & 22 & 8,522 & 0,000 & $\begin{array}{c}\mathrm{I}-\mathrm{III} \\
\mathrm{p}=0,000 \\
\mathrm{II}-\mathrm{III} \\
\mathrm{p}=0,008\end{array}$ \\
\hline $\begin{array}{l}\text { Świado- } \\
\text { mość celu }\end{array}$ & 4,90 & 0,805 & 22 & 4,77 & 1,149 & 18 & 4,18 & 0,958 & 22 & 3,471 & 0,037 & Brak \\
\hline $\begin{array}{l}\text { Poczucie } \\
\text { wolności }\end{array}$ & 4,75 & 1,270 & 22 & 4,08 & 1,320 & 18 & 3,86 & 1,177 & 22 & 2,956 & 0,059 & Brak \\
\hline $\begin{array}{l}\text { Ocena } \\
\text { przyszło- } \\
\text { ści }\end{array}$ & 5,09 & 0,921 & 22 & 4,50 & 1,124 & 18 & 4,31 & 1,006 & 22 & 3,458 & 0,038 & Brak \\
\hline $\begin{array}{l}\text { Postawa } \\
\text { wobec } \\
\text { śmierci }\end{array}$ & 5,04 & 0,999 & 22 & 4,52 & 1,050 & 18 & 4,75 & 1,142 & 22 & 1,191 & 0,310 & Brak \\
\hline
\end{tabular}

Źródło: opracowanie własne.

większość badanych akceptuje również fakt zbliżającej się śmierci. Duży wpływ na to, w jaki sposób osoba starsza postrzega wizję własnej śmierci, ma nastawienie do własnego życia. Jeżeli dla seniora jego życie jest wartościowe, wtedy śmierć zdaje się być możliwa do zaakceptowania. Co ważne i co wykazały niniejsze badania, osoby starsze akceptują swe słabości i to, co im życie przyniosło, bez poczucia porażki. Akceptują siebie takimi, jakimi są. Istotne jest to dla ludzi pomagających osobom starszym, ponieważ dzięki temu istnieje większe prawdopodobieństwo, że ich pomoc nie zostanie odrzucona lub odebrana jako atak. Seniorzy najniżej oceniali poczucie własnej wolności. Trudno jest jednoznacznie określić, co może być tego przyczyną i jakie czynniki mogą ograniczać wolność osób starszych. Zdaniem K. Kędziory-Kornatowskiej i A. Grzanki-Tykwińskiej (2011, s. 107) „osoby w podeszłym wieku sądzą, że nie nadążając za postępem technicznym, nie tylko są bezużyteczne, ale również tracą autorytet. Uważają również, że współczesne społeczeństwo postrzega je jako obciążenie i przeszkodę w osiąganiu przez nie postępu i dobrobytu". Podążając za słowami autorek, możliwe jest stwierdzenie, że postęp techniczny może mieć wpływ na poczucie ograniczenia wolności przez osoby starsze. 
Chcąc dokładnie zdiagnozować, jak wysokie natężenie poczucia sensu życia posiadają osoby starsze, należałoby przeprowadzić dokładniejsze badania na większej liczbie ankietowanych. Ze względu na to, że w Polsce oraz w innych krajach na całym świecie występuje zjawisko starzejącej się ludności, istotne jest wszechstronne zainteresowanie się problematyką osób starszych, w tym problemami natury psychologicznej i egzystencjalnej.

\section{BIBLIOGRAFIA}

Dyczewski L. (1994), Ludzie starzy i starość w społeczeństwie i kulturze, Lublin: Redakcja Wydawnictw KUL.

Grzywna A. (2013), Jak oswoić się z myśla o starości, umieraniu i śmierci, Lublin: Wydawnictwo Słowa i Myśli.

GUS (2014), Sytuacja demograficzna osób starszych i konsekwencje starzenia się struktury ludności w świetle prognozy na lata 2014-2050, Warszawa, www.opzz.org.pl/documents/1137115/0/ ludnosc w starszym wieku.pdf (dostęp: 05.01.2016).

Izdebski P., Polak A. (2005), Bilans życia, poczucie koherencji i aktualna sytuacja życiowa, „Gerontologia Polska", 3 (13).

Juza S. (2012), Charakterystyka osobowościowa więźniów w kontekście ich zdrowienia, [w:] E. Drop, M. Maćkiewicz (red.), Młoda psychologia, t. 1, Warszawa: Wydawnictwo Liberi Libri.

Kędziora-Kornatowska K., Grzanka-Tykwińska A. (2011), Osoby starsze w społeczeństwie informacyjnym, „Gerontologia Polska”, 19 (2).

Mariański J. (2013), Sens życia, wartości, religia - studium socjologiczne, Lublin: Wydawnictwo KUL.

Mizińska J. (2011), Dobrobyt a dobrostan, czyli kiedy sens jest bez sensu, [w:] D. Probucka (red.), Etyka i sens życia, Kraków: Wydawnictwa Naukowe Uniwersytetu Pedagogicznego.

Pichalski R. (2014), Psychospołeczne uwarunkowania funkcjonowania osób w podeszłym wieku, Toruń: Wydawnictwo Adam Marszałek.

Pilch T. (1995), Zasady badań pedagogicznych, Warszawa: Wydawnictwo Akademickie Żak.

Sikorski T. (1989), Sens życia, [w:] A. Zuberbier (red.), Stownik teologiczny, cz. 2, Katowice: Wydawnictwo Księgarnia Świętego Jacka.

Szarota Z. (2004), Gerontologia społeczna i oświatowa. Zarys problematyki, Kraków: Wydawnictwo Naukowe Akademii Pedagogicznej.

Szatur-Jaworska B. (2000), Ludzie starzy i starość w polityce społecznej, Warszawa: Wydawnictwo Aspra-jr.

Trafiałek E. (2003), Człowiek stary, [w:] T. Pilch (red.), Encyklopedia pedagogiczna XXI wieku, t. 1, Warszawa: Wydawnictwo Żak.

Trafiałek E. (2006), Starzenie się i starość. Wybór tekstów z gerontologii społecznej, Kielce: Wydawnictwo Uczelniane Wszechnica Świętokrzyska.

Zegarow P. (2015), Poczucie sensu życia chroni Twoje serce, „Psychologia Zdrowia”, http://psychologiazdrowia.pl/poczucie-sensu-zycia-chroni-twoje-serce (dostęp: 08.12.2015). 


\section{SUMMARY}

Getting old is not a new phenomenon. People have been getting old for ages - it is normal. However, over the recent years it can be observed that Polish society is ageing. It happens as progress in medicine gives the opportunity to increase average lifespan; at the same time the birth rate is decreasing dramatically. The elderlies are becoming more and more numerous group. That is why it is important to get knowledge on the ageing process as well as on the problems of existential nature including the sense of the life meaning among the people entering into the old age.

Keywords: old age; aging; old people; purpose in life 